\title{
THE BETHESDA SYSTEM FOR REPORTING THYROID CYTOLOGY - UNIFORM TERMINOLOGY TO AID IN THE MANAGEMENT OF THYROID LESIONS: STUDY IN KMCH
}

\author{
Mahathi Thotakura ${ }^{1}$, Y. Krishna Bharathi ${ }^{2}$, (Maj) Suma Kaza ${ }^{3}$, R. Nageswara Rao 4 \\ ${ }^{1}$ Assistant Professor, Department of Pathology, Katuri Medical College and Hospital. \\ 2 Professor, Department of Pathology, Katuri Medical College and Hospital. \\ ${ }^{3}$ Assistant Professor, Department of Pathology, Katuri Medical College and Hospital. \\ ${ }^{4}$ Professor \& HOD, Department of Pathology, Katuri Medical College and Hospital.
}

\section{ABSTRACT}

\section{BACKGROUND}

Fine needle aspiration has been widely accepted as diagnostic procedure of choice in assessment of non-toxic thyroid nodule. Despite thyroid cytology being widely used as a first-line investigation to guide clinical management, until recently there was no standardized terminology for FNAC reporting. The Bethesda system for reporting thyroid cytology (TBSRTC) has attempted to standardize reporting in aspiration smears.

\begin{abstract}
AIMS
The objective of the present study was to report thyroid cytology smears by TBSRTC into various categories, analyse their cytological features using TBSRTC monograph, conveying brief management plan to clinicians and correlated with histopathology specimens whenever they are available.

\section{MATERIALS AND METHODS}

A total of 138 patients who presented with thyroid swelling were subjected to thyroid Fine Needle Aspiration Cytology (FNAC) and the smears were made followed by $\mathrm{H}$ and $\mathrm{E}$ staining. The Bethesda system for reporting thyroid cytology was followed on aspiration smears using criteria published in the atlas and related literature. The clinicians were communicated implied risk of malignancy and recommended clinical management along with report. Histopathology specimens whenever received were processed as per standard methods. Sensitivity, specificity, positive predictive value, and negative predictive value were calculated using histopathology diagnosis as gold standard results: Distribution of 138 cases as per Bethesda system of reporting was done. Benign category was the largest (75.4\%) followed by ND/UNS category (8.7\%), malignant and SFM constitutes $2.9 \%$ and $4.3 \%$ total $7.2 \%$, AUS/FLUS constitutes $5.8 \%$, while FN/SFN constitutes $2.9 \%$. If FN/SFN is included in malignant group the sensitivity increases, but the specificity decreases. There is marked decrease in positive predictive value.
\end{abstract}

\section{CONCLUSION}

Our findings were consistent with others, who used the Bethesda cytopathology reporting system. Applying a standard terminology reporting system for thyroid, FNA may enhance the communication between pathologists and clinicians, assists them to find out the rate of malignancy in each cytological group and facilitating a more consistent approach for patients management.

\section{KEYWORDS}

Fine Needle Aspiration Cytology (FNAC), The Bethesda System for Reporting Thyroid Cytopathology (TBSRTC), Non-Diagnostic or Unsatisfactory (ND/UNS), Atypia of undetermined significance or follicular lesion of undetermined significance (AUS/FLUS), Follicular Neoplasm or Suspicious for Follicular Neoplasm (FN/SFN), Suspicious for Malignancy (SFM), Lymphocytic Thyroiditis (LT), Benign Follicular Nodule (BFN), Papillary Thyroid Carcinoma (PTC).

HOW TO CITE THIS ARTICLE: Mahathi Thotakura, Y. Krishna Bharathi, (Maj) Suma Kaza, R. Nageswara Rao. "The Bethesda System for Reporting Thyroid Cytology-Uniform Terminology to Aid in the Management of Thyroid Lesions: Study in KMCH." Journal of Evolution of Medical and Dental Sciences 2015; Vol. 4, Issue 97, December 03; Page: 16273-16279, DOI: $10.14260 /$ jemds/2015/2399

\section{INTRODUCTION}

Fine needle aspiration has been widely accepted as diagnostic procedure of choice assessment of non-toxic thyroid nodule.(1,2)

Financial or Other, Competing Interest: None.

Submission 17-11-2015, Peer Review 18-11-2015,

Acceptance 27-11-2015, Published 03-12-2015.

Corresponding Author:

Dr. Mahathi Thotakura

Assistant Professor, Department of Pathology,

Katuri Medical College and Hospital, Katuri Nagar,

Chinakondrupadu, Guntur-522019, Andhra Pradesh.

E-mail: amsmakineni@gmail.com

DOI:10.14260/jemds/2015/2399
It reduces the rate of unnecessary thyroid surgery for patients with benign nodules. $(3)$

Despite thyroid cytology being widely used as a first-line investigation to guide clinical management, until recently there was no standardized terminology for FNAC reporting.(3)

It is critical that cytopathologists communicate thyroid FNA interpretations to referring physicians. The terminology of reporting the thyroid FNAC has varied markedly, creating confusions in some cases and hindering the sharing of clinically meaningful data.(3,4) Recently to address terminology and other issues related to thyroid fine needle aspiration, the National Cancer Institute $(\mathrm{NCI})$ hosted the 
"NCI thyroid fine needle aspiration state of the science conference" at Bethesda Marylandin 2007. $(5,6)$

A monograph "The Bethesda System for reporting thyroid cytopathology" (TBSRTC), which includes the definitions, diagnostic/morphological criteria, explanatory notes, and a brief management plan for each diagnostic category was published. TBSRTC is a six-category scheme of thyroid cytopathology reporting. Each category has implied cancer risk, which ranges from $0 \%$ to $3 \%$ for the "benign" category to virtually $100 \%$ for "Malignant" category.(7,8) It uses three categories, AUS/FLUS, FN/SFN and SFM to report thyroid aspirates that fall between benign and malignant as shown in Table 1.

\section{AIMS AND OBJECTIVES}

The objective of the present study was to report thyroid cytology smears by TBSRTC into various categories, analyse their cytological features using TBSRTC monograph, conveying brief management plan to clinicians and correlated with histology specimens wherever it is available. This study provides rational approach to management and to determine the correct surgical procedure when it is required.

\section{MATERIAL AND METHODS}

A total of 138 cases of thyroid nodules referred to Pathology Department, KMCH, from November 2014 to October 2015. Thyroid swellings were aspirated as per standard procedures.(9) All the slides were stained with $\mathrm{H}$ and E stain. We categorized our results into nondiagnostic or unsatisfactory, benign, atypical follicular lesion of undetermined significance, follicular neoplasm, suspicious for malignancy, and malignancy according to the recent Bethesda classification. (4)

The clinicians were communicated implied risk of malignancy and recommended clinical management along with report. Histopathology specimens whenever available were processed as per standard methods. Sensitivity, specificity, positive predictive value, and negative predictive value were calculated using histopathology diagnosis as gold standard. For calculating statistical parameters ND/UNS and AUS/FLUS cases were excluded as non-definitive diagnosis and categories "SFM" and "Malignant" were put together. All other parameters were calculated either excluding FN/SFN or including it with either benign or malignant

\section{RESULTS}

Distribution of 138 cases as per Bethesda system of reporting was done as shown in Table 2. Benign category was the largest $(75.4 \%)$ followed by ND/UNS category $(8.7 \%)$, malignant and SFM constitutes $2.9 \%$ and $4.3 \%$, total $7.2 \%$, AUS/FLUS constitutes 5.8\%, while FN/SFN constitutes $2.9 \%$.

In the ND/UNS category all cases were subcategorised as cyst fluid only. In benign category, the subcategories Benign Follicular Nodule (BFN) constitute 73\%, Lymphocytic Thyroiditis (LT) constitute $23 \%$, granulomatous thyroiditis constitute $2 \%$ and in 'Others' include a case of abscess constitutes $2 \%$. The pus was negative for acid fast bacilli and fungus. In SFM category, 83\% were suspicious for papillary carcinoma and $17 \%$ were suspected for medullary carcinoma. Malignant categories included 4(2.9\%) cases. All of them are diagnosed as papillary carcinoma.
Out of 138 cases that were cytological reported, we received $28(20 \%)$ cases of histopathological specimens. Two cases in ND/UNS categories, 16 cases in benign categories, 1 case in AUS/FLUS categories, 3 cases in FN/SFN categories, 4 cases in SFM categories and 2 cases in malignancy categories were received as shown in Table 3.

Out of 3 cases of FN/SFN, 2 were benign (Follicular adenomas) and 1 was malignant (Papillary thyroid carcinoma). Out of 4 cases of SFM, 2 of them turned out be papillary thyroid carcinoma, but 2 were benign, one is nodular goiter and the other one is follicular adenoma. Histopathology was received for 2 cases of malignant category, both of them turned out to be papillary carcinoma. Fifteen cases were benign by both cytopathology and histopathology. Two cases were malignant by both cytopathology and histopathology. None of the cases with a malignant diagnosis on cytology proven to be benign on biopsy. One case out of 16 that were benign on cytology was proven to be malignant lesion on histopathology examination. It was shown in Table 4.

\section{DISCUSSION}

Thyroid nodules are common clinical problem and FNAC of thyroid is the key preoperative investigation of thyroid lesions. Fortunately, the vast majority of nodules are benign, but when they are discovered an assessment regarding the need to exclude malignancy using FNA must be performed.(10)

The present data shows that introduction of the new simplified Bethesda thyroid reporting system into six categories logically related to the prognosis of thyroid diseases and may increase the reproducibility of diagnosis.(11) Each diagnostic category convey specific risks of malignancy, which offers guidance for patient management.(12) The present study had $12(8.7 \%)$ cases in ND/UNS category. Other recent studies had $6.2 \%-18.6 \%$ cases in this category.(13-16) The guidelines for this category are very clear in TBSRTC. Nodules with an initial ND/UNS result should be re-aspirated, but not sooner than 3 months later. The 3 months interval is recommended to prevent false-positive interpretation due to reactive/reparative changes.(17) TBSRTC does not provide the implied risk of malignancy for this category. Two histopathological specimen were received and showed nodular goiter. Surgeons were not comfortable with the term ND/UNS and not willing to wait for 3 months, thus preferred to go for surgery.

The benign category had 104 cases $(75.4 \%)$ with benign follicular nodule being the predominant group followed by lymphocytic thyroiditis. Other recent studies had 57.3\%$73.8 \%$ cases in this category.(13-16) Sixteen histopathological specimens from benign category were received. All of them were operated because of pressure symptoms or cosmetic reason. Out of sixteen, 12 were nodular goiter, 3 were follicular adenoma, and 1 was PTC. Three cases of follicular adenoma had abundant colloid in addition to a few follicular cells on cytology, hence were diagnosed as BFN. The cytological appearance of nodular goiter can overlap with those of follicular adenoma and cytological criteria alone cannot reliably distinguish between the two in certain cases.(18)

There was one case of PTC, which is less than $1 \mathrm{~cm}$ size on histopathology specimen diagnosed as BFN on cytology. 
There were no lymph node enlargement and ultrasound features are not suspicious. These remain indolent in most case study by Harach et al.(19) TBSTRC recommended on diagnostic terminology and morphological criteria mentioned giant cells and epithelioid cells in lymphocytic thyroiditis is not described in the previous literature. $(20,21)$

The classification of "Indeterminate" lesion (Those not clearly benign or malignant) in thyroid cytopathology has long been a source of confusion for both pathologists and clinicians. The general category AUS/FLUS is received for specimens that contained cells (Follicular, lymphoid, or other) with architectural and/or nuclear atypia that is not sufficient to be classified as suspicious for a follicular neoplasm or suspicious for malignant or malignant. The atypia is more marked than can be ascribed confidently to benign changes.(22) In present study, 8 cases $(5.8 \%)$ in AUS/FLUS category. Other recent studies show 3.0\%-13.6\% cases; $13.6 \%$ was highest according to M.M. Al-Shraim et al. This is a category of last resort and should not be used indiscriminately. The recommended management for an initial AUS/FLUS, repeat FNA at an appropriate interval. One case of AUS/FLUS on cytology proved to be malignant on histology and was PTC.

FN/SFN category had 4 cases (2.9\%). Recent studies have shown $3 \%-16.1 \%$ cases.(13-16) Histopathological specimens were received, one was turned to be papillary thyroid carcinoma which had predominant follicular pattern without classical nuclear features in cytological smears.

SFM categorie 6 (4.3\%), 5 of which were suspicious for papillary carcinoma, one was suspicious for papillary carcinoma, one was suspicious for medullary carcinoma. Recent studies has shown $1.3 \%-3.5 \%$ cases.(13-16)

Histopathology was received for 4 cases, all are reported as papillary carcinomaon cytology. Histopathologically, two of them turned to be papillary carcinoma, but one is follicular adenoma and other one is nodular goiter. The latter were on cytology diagnosed as PTC, because high cellularity and intranuclear cytoplasmic inclusions. Though intranuclear cytoplasmic inclusions are not specific for PTC, as they may be seen focally in benign thyroid nodules, but diagnosis of suspicious for PTC was given so as not to miss out malignancy.

The present study had 4 cases $(2.9 \%)$ in malignant categories. Other recent studies show 2.9\%-7.6\% cases.(13-16) Histopathology was received for 2 cases of malignant, both of them turned out to be papillary thyroid carcinoma. Fifteen cases were benign by both cytology as well as histopathology. Two cases were malignant by both cytology and histopathology. None of the case with a malignant diagnosis on cytology proven to be benign on histopathology. One case out of 16 that were benign on cytology proven to be malignant lesion on histopathological examination.

The method of data analysis can alter the results of statistical parameters. If $\mathrm{FN} / \mathrm{SFN}$ is included in malignant group, the sensitivity increases but specificity decreases. There is marked decrease in positive predictive value. If FN/SFN lesions are excluded, the sensitivity decrease and false negative rates increases shown in Table 5.

When compared with similar studies, we found that our findings were consistent with other studies as shown in Table 6. Other studies like Gharib, et al.(23) and Yassa L, et al.(24) which was conducted on 731 and 268 cases respectively, also showed that by adopting the Bethesda system of reporting a higher level of sensitivity (99.3\% and $98.6 \%$ ) can be achieved as shown in Table 6 .

\section{CONCLUSION}

Applying a standard terminology reporting system for thyroid FNA, may enhance the communication between pathologists and clinicians, assists them to find out the rate of malignancy in each cytological group and facilitating a more consistent approach for patient's management.

\section{REFERENCES}

1. Mazzaferri EL. Management of a solitary thyroid nodule. N Engl j Med 1993;328:553-559.

2. Cooper DS, Doherty GM, Haugen BR, et al. American Thyroid Association Guidelines Taskforce. Management guidelines for patients with thyroid nodules and differentiated thyroid cancer. Thyroid 2006;2:109-142.

3. Redman R, Yoder BJ, Massoll N. Perception of diagnostic terminology and cytopathology reporting of fine needle aspiration biopsies of thyroid nodules: a survey of clinicians and pathologists; Thyroid 2006;16:1003-1008.

4. Ali SZ, Cibas ES. The Bethesda System for Reporting Thyroid Cytopathology. Definitions, Criteria and Explanatory Notes. New York, NY, USA: Springer; 2010.

5. Cibas ES, Sanchez MA. The National Cancer Institute Thyroid Fine-Needle Aspiration State-of-the-Science Conference: inspiration for a uniform terminology linked to management guidelines. Cancer 2008;2:71-73.

6. Baloch ZW, LiVolsi VA, Asa SL, et al. Diagnostic terminology and morphologic criteria for cytologic diagnosis of thyroid lesions: a synopsis of the National Cancer Institute Thyroid Fine-Needle Aspiration State of the Science Conference. Diagn Cytopathol 2008;6:425437.

7. Basharat R, Bukhari MH, Saud S, Hamid T. Comparision of fine needle aspiration cytology and thyroid scan in solitary thyroid nodule. Pathology Res int 2011: 754041

8. Bongiovanni M, Spitate A, Faquin WC, Mazzucchelli L, Baloch ZW. The Bethesda system for reporting thyroid cytopathology: A meta analysis Acta cytol 2012;56:333339.

9. Smit TJ, Safali H, Foster EA, Reinhold RB. Accuracy and cost-effectiveness of fine needle aspiration biopsy Am J Surg 149 (1985), pp. 540-555.

10. Langer JE, Baloch ZW, McGrath C, Loevner LA, Mandel SJ. Thyroid nodule fine needle aspiration. Semin ultrasound CT MR, 2012;33:158-16.

11. Poller DN, Stelow EB, Yiangou C. Thyroid FNAC cytology: Can we do it better? Cytopathology, 2008;19:4-10.

12. Theoharis CG, Schofield KM, Hammers L, Udelsman R, Chhieng DC. The Bethesda thyroid fine needle aspiration classification system: Year 1 at an academic Institution. Thyroid 2009;19:1215-1223.

13. Yang J, Schnadig V, Logrono R, Wasserman PG. Fineneedle aspiration of thyroid nodules: a study of 4703 patients with histologic and clinical correlations. Cancer 2007;111(5):306-315.

14. Jo VY, Stelow EB, Dustin SM, and Hanley KZ. Malignancy risk for fine needle aspiration of thyroid lesions according to the Bethesda system for reporting thyroid cytopathology. The American Journal of clinical Pathology, vol.134, no.3, pp. 450-456, 2010. 
15. Bonzanini M, Amdori P, Morelli L, et al. "Subclassification of the 'grey zone' of thyroid cytology: a retrospective descriptive study with clinical, cytology, and histopathology correlation." Journal of Thyroid Research, vol. 2011, Article ID 251680, 8 pages, 2011.

16. Al-Shraim MM, Kaood OM, Hussein MR, et al. "Assessment of malignancy rate in thyroid nodule according to the Bethesda system of fine needle aspiration: report from a Tertiary Center in the Southwestern Region of Saudi Arabia" Saudi Medical Journal, vol 33, no.2, pp.167-171, 2012.

17. Layfield LJ, Abrams J, Cochand-Priollet B, et al. Postthyroid FNA testing and treatment options: a synopsis of the National Cancer Institute Thyroid Fine Needle Aspiration State of the Science Conference. Diagn Cytopathology 2008;36(6);442-448.

18. Layfield LJ, Morton MJ, Cramer HM, et al. Implications of the proposed thyroid fine-needle aspiration category of "follicular lesion of undetermined significance:" a fiveyear multi-institutional analysis. Diagn Cytopathol 2009;10:710-714.

19. Orell SR, Sterrett GF, and Whitaker D. "Chapter 6 . Thyroid" in Fine Needle Aspiration Cytology, pp.125-164, Elseveir, Sydney, Australia 2005.

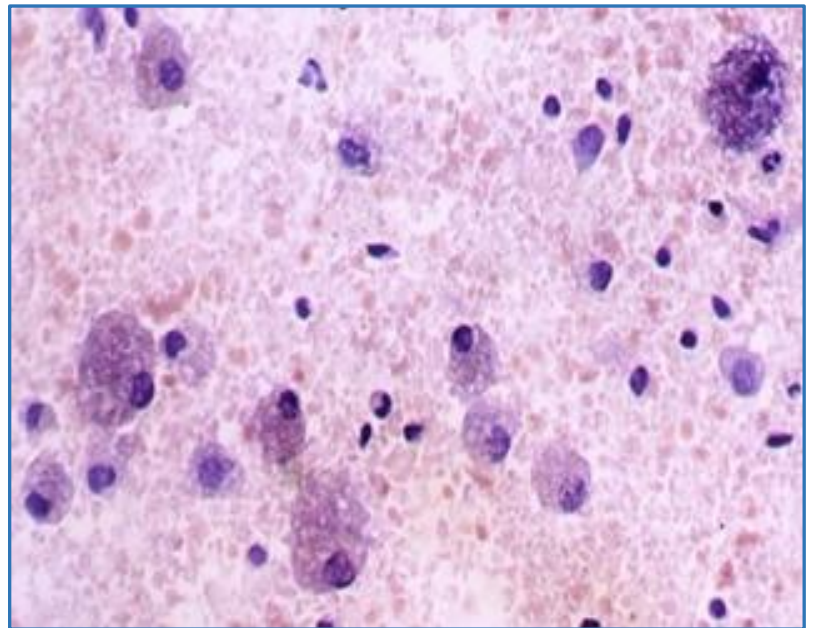

Fig. 1: Benign Follicular Nodule
20. Harach HR, Franssila KO, and Wasenius VM. "Occult papillary carcinoma of the thyroid. A 'normal' finding in Finland. A systemic autopsy study" Cancer, vol. 56, no. 3, pp.531-538, 1985.

21. Person PS. "Cytodiagnosis of thyroiditis. A comparative study of cytological, histological, immunological and clinical findings in thyroiditis, particularly in diffuse lymphoid thyroiditis" Acta Medica Scandinavica, vol. 483, pp 7-100, 1968.

22. Bhalotra $\mathrm{R}$ and Jayaram G. "Overlapping morphology in thyroiditis (Hashimoto's and subacute) and Grave's disease" Cytopathology, vol. no.6, pp 371-372, 1990.

23. Wang HH. Reporting thyroid fine-needle aspiration: literature review and a proposal. Diagnostic Cytopathology 2006;34(1):67-76.

24. Gharib H, Goellner JR. Fine-needle aspiration biopsy of the thyroid: an appraisal. Annals of Internal Medicine 1993;118(4):282-289.

25. Yassa L, Cibas ES, Benson CB, et al. Long-term assessment of a multidisciplinary approach to thyroid nodule diagnostic evaluation. Cancer 2007;111(6):508-516.

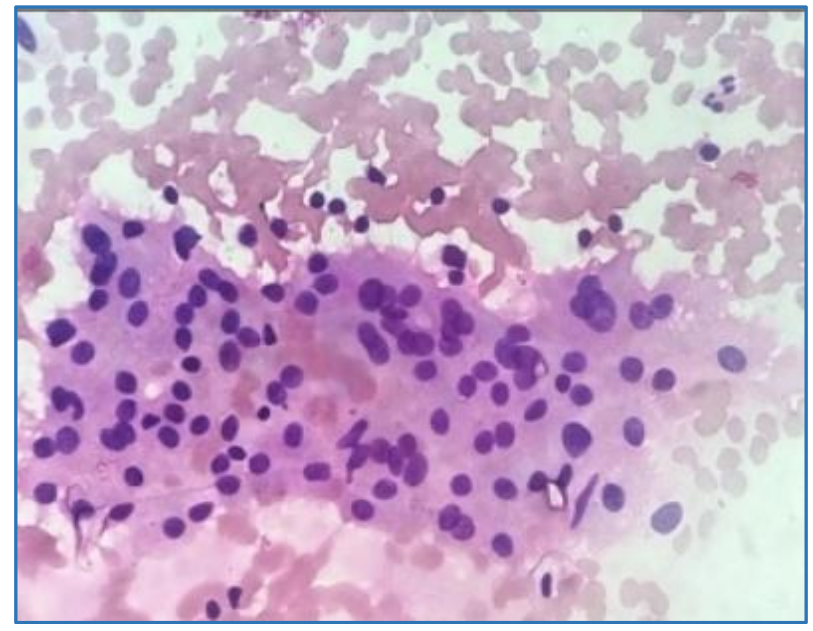

Fig. 2: Hashimoto Thyroiditis
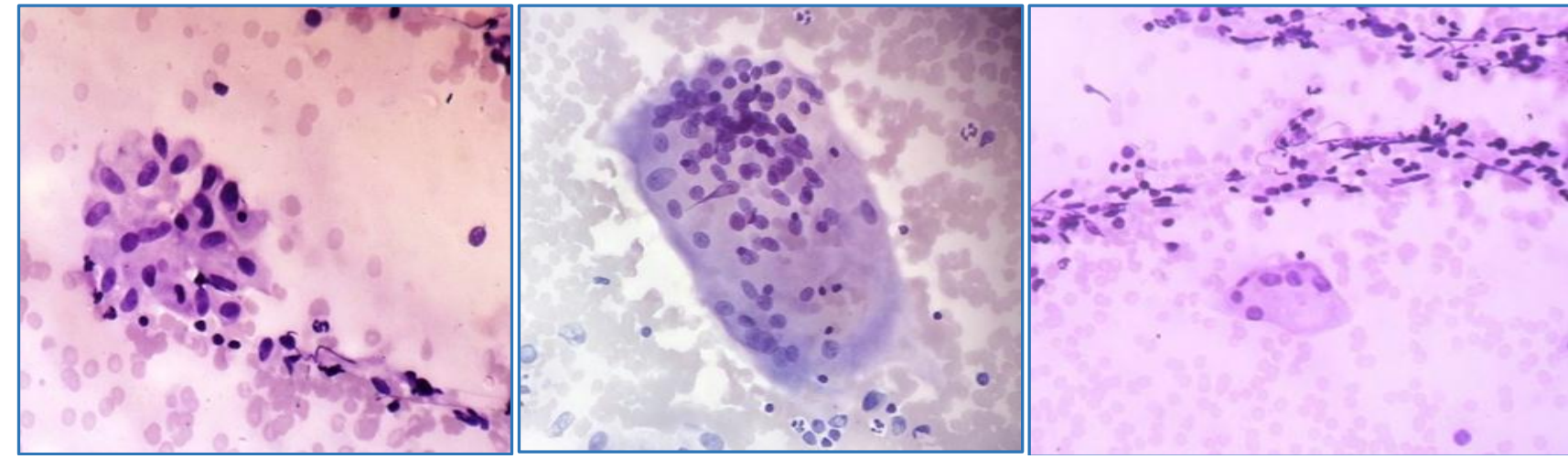

Fig. 3: Granulomatous Thyroiditis 


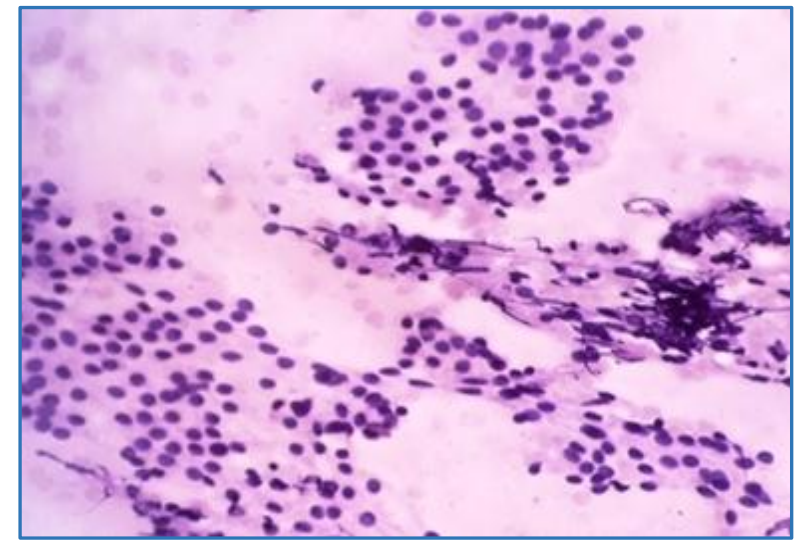

Fig. 4: Atypia of Undeterminate Significance

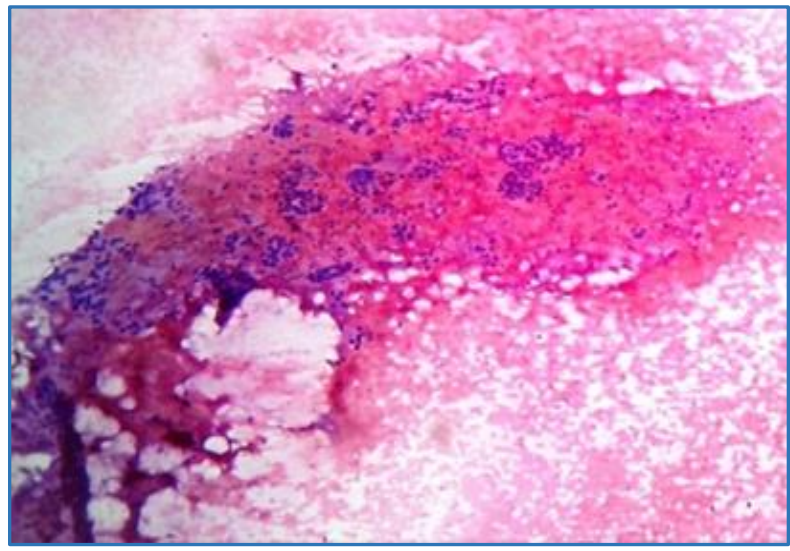

Fig. 5: Follicular Neoplasm/Suspicious for a Follicular Neoplasm

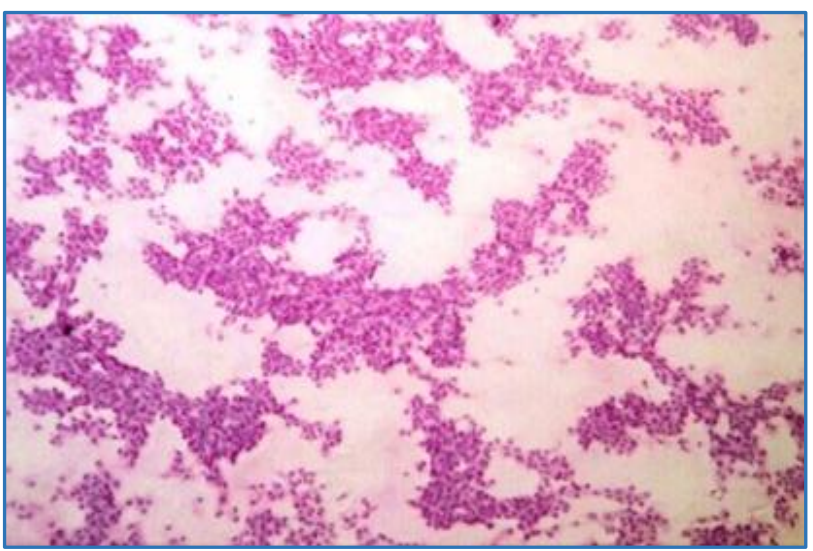

Fig. 6 : Papillary Carcinoma of Thyroid

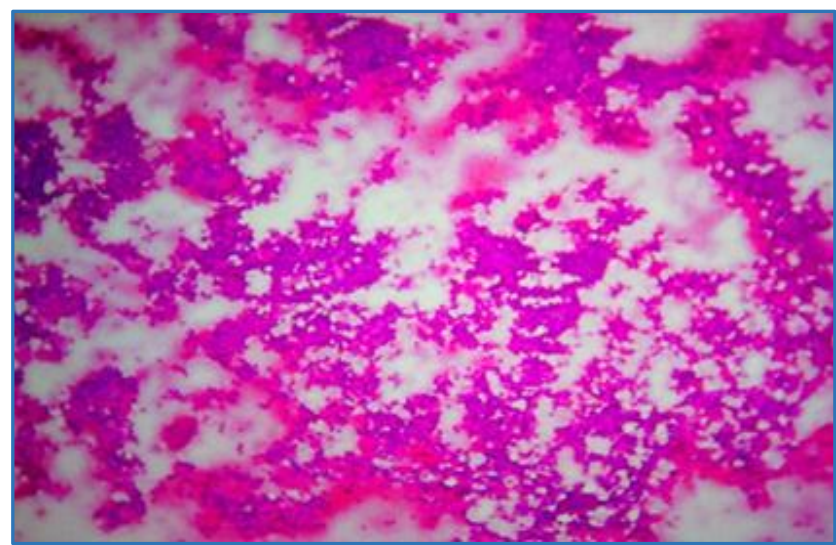

Fig. 7: Suspicious for Medullary Carcinoma of Thyroid

\begin{tabular}{|c|c|c|c|}
\hline $\begin{array}{l}\text { Sl. } \\
\text { No. }\end{array}$ & Diagnostic Category & $\begin{array}{c}\text { Risk of } \\
\text { Malignancy }\end{array}$ & Usual Management \\
\hline (I) & $\begin{array}{l}\text { Nondiagnostic or unsatisfactory } \\
\text { (ND/UNS) } \\
\text { Cyst fluid only Virtually acellular specimen Other (obscuring blood, } \\
\text { clotting artifact, etc.) }\end{array}$ & & $\begin{array}{l}\text { Repeat FNA with } \\
\text { ultrasound guidance }\end{array}$ \\
\hline (II) & $\begin{array}{l}\text { Benign } \\
\text { Consistent with a benign follicular nodule } \\
\text { (Includes adenomatoid nodule, colloid nodule etc.) } \\
\text { Consistent with lymphocytic(Hashimoto's) thyroiditis } \\
\text { In the proper clinical context consistent with granulomatous } \\
\text { (Subacute) thyroiditis other }\end{array}$ & $0-3 \%$ & Clinical follow-up \\
\hline (III) & $\begin{array}{l}\text { Atypia of undetermined significance or } \\
\text { follicular lesion of undetermined significance } \\
\text { (AUS/FLUS) }\end{array}$ & $5-15 \%$ & Repeat FNA \\
\hline (IV) & $\begin{array}{l}\text { Follicular neoplasm or suspicious for } \\
\text { Follicular neoplasm (FN/SFN)-Specify if Hurthle cell (oncocytic) type }\end{array}$ & $15-30 \%$ & Surgical lobectomy \\
\hline (V) & $\begin{array}{l}\text { Suspicious for malignancy (SFM) } \\
\text { Suspicious for papillary carcinoma, Suspicious for medullary carcinoma } \\
\text { Suspicious for metastatic carcinoma, Suspicious for lymphoma other }\end{array}$ & $60-75 \%$ & $\begin{array}{l}\text { Near-total thyroidectomy } \\
\text { or Surgical lobectomy }\end{array}$ \\
\hline (VI) & $\begin{array}{l}\text { Malignant } \\
\text { Papillary thyroid carcinoma, Poorly differentiated carcinoma, Medullary } \\
\text { thyroid carcinoma } \\
\text { Undifferentiated (anaplastic) carcinoma, Squamous cell carcinoma } \\
\text { Carcinoma with mixed features (specify), Metastastic carcinoma } \\
\text { Non-Hodgkin's lymphoma other }\end{array}$ & $97-99 \%$ & Near-total tyroidectomy \\
\hline
\end{tabular}




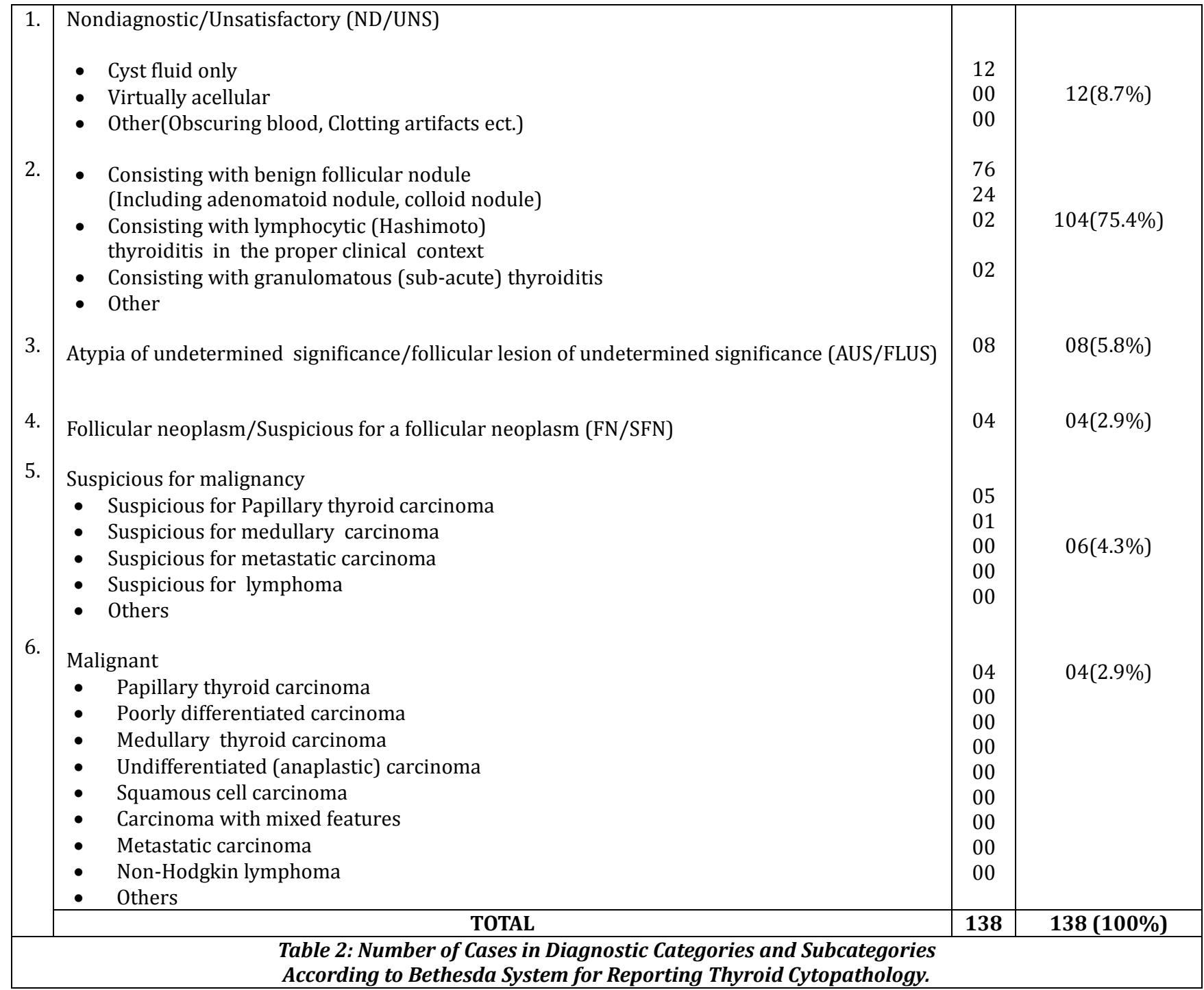

\begin{tabular}{|c|c|c|c|}
\hline CYTOLOGICAL CATEGORIES & $\begin{array}{l}\text { NUMBER OF CASES SURGICAL } \\
\text { SPECIMENS WERE RECEIVED }\end{array}$ & $\begin{array}{l}\text { HISTOPATHOLOGICAL } \\
\text { DIAGNOSIS }\end{array}$ & NUMBER OF CASES \\
\hline ND/UNS(n=12) & 02 & Nodular goiter & 02 \\
\hline $\operatorname{Benign}(n=104)$ & 16 & $\begin{array}{c}\text { Nodular goiter } \\
\text { Follicular adenoma } \\
\text { Papillary thyroid carcinoma }\end{array}$ & $\begin{array}{l}12 \\
03 \\
01\end{array}$ \\
\hline AUS/FLUS (n=08) & 01 & Papillary thyroid carcinoma & 01 \\
\hline FN/SFN (n=04) & 03 & $\begin{array}{c}\text { Follicular adenoma } \\
\text { Papillary thyroid carcinoma }\end{array}$ & $\begin{array}{l}02 \\
01\end{array}$ \\
\hline SFM $(n=06)$ & 04 & $\begin{array}{c}\text { Nodular goiter } \\
\text { Follicular adenoma } \\
\text { Papillary thyroid carcinoma }\end{array}$ & $\begin{array}{l}01 \\
01 \\
02\end{array}$ \\
\hline Malignant & 02 & Papillary thyroid carcinoma & 02 \\
\hline
\end{tabular}

\begin{tabular}{|ccc|}
\hline CYTODIAGNOSIS & HISTOLOGICAL DIAGNOSIS & MALIGNANT \\
\hline ND/UNS(n=02) & 02 & 00 \\
Benign(n=16) & 15 & 01 \\
AUS/FLUS (n=01) & 00 & 01 \\
FN/SFN (n=03) & 02 & 01 \\
SFM ( $=04)$ & 02 & 02 \\
Malignant (N=02) & 00 & 02 \\
\hline Table 4: Cytology Diagnosis with Histological Correlation with Benign and Malignant Cases \\
\hline
\end{tabular}




\begin{tabular}{|c|c|c|c|c|}
\hline Study & Sensitivity \% & Specificity\% & $\begin{array}{c}\text { Positive } \\
\text { Predictive Value PPV\% }\end{array}$ & $\begin{array}{c}\text { Negative } \\
\text { Predictive Value NPV\% }\end{array}$ \\
\hline $\begin{array}{c}\text { PRESENT STUDY } \\
\text { FN/SFN } \\
\text { Cases excluded } \\
\text { FN/SFN }\end{array}$ & $71.4 \%$ & $89.4 \%$ & $71.4 \%$ & $89.4 \%$ \\
$\begin{array}{c}\text { Cases included as benign } \\
\text { FN/SFN }\end{array}$ & $75 \%$ & $90.4 \%$ & $75 \%$ & $90.4 \%$ \\
Cases included as malignant & $85.7 \%$ & $82.6 \%$ & $60 \%$ & $95 \%$ \\
\hline \multicolumn{3}{r|}{ Table 5: Statistical Parameters When FN/SFN Cases Excluded } \\
or Included in Benign and Malignant Cases
\end{tabular}

\begin{tabular}{|c|c|c|c|c|c|c|c|}
\hline Study & $\begin{array}{c}\text { Ko } \\
\text { et } \\
\text { al. }\end{array}$ & $\begin{array}{c}\text { Kessler } \\
\text { et al. }\end{array}$ & $\begin{array}{c}\text { Handa } \\
\text { et al. }\end{array}$ & $\begin{array}{c}\text { Gupta } \\
\text { et al. }\end{array}$ & $\begin{array}{c}\text { Present Study } \\
\text { (FN/SFN } \\
\text { Excluded) }\end{array}$ & $\begin{array}{c}\text { Present Study } \\
\text { (FN/SFN Included } \\
\text { as Benign) }\end{array}$ & $\begin{array}{c}\text { Present Study (FN/SFN } \\
\text { Included as Malignant) }\end{array}$ \\
\hline Sensitivity\% & 78.4 & 79 & 97 & 80 & 71.4 & 75 & 85.7 \\
\hline Specificity\% & 98.2 & 98.5 & 100 & 86.6 & 89.4 & 90.4 & 82.6 \\
\hline PPV\% & 99 & 98.7 & 96 & 80 & 71.4 & 75 & 60 \\
\hline NPV\% & 66.3 & 76.6 & 100 & 86.6 & 89.4 & 90.4 & 95 \\
\hline \multicolumn{7}{|c|}{ Table 6: The Results of Various Statistical Parameters Compared with Other Studies are Summarised } \\
\hline
\end{tabular}

